\begin{abstract}
Iranica
Abstracta Iranica Revue bibliographique pour le domaine irano-aryen

Volume 32-33 | 2013

Comptes rendus des publications de 2009-2010
\end{abstract}

\title{
James Howard-Johnston. The Sasanians' Strategic Dilemma
}

\author{
Michael Richard Jackson Bonner
}

\section{(2) OpenEdition}

1 Journals

Édition électronique

URL : http://journals.openedition.org/abstractairanica/40518

DOI : 10.4000/abstractairanica.40518

ISSN : 1961-960X

\section{Éditeur :}

CNRS (UMR 7528 Mondes iraniens et indiens), Éditions de l'IFRI

\section{Édition imprimée}

Date de publication : 1 décembre 2013

ISSN : 0240-8910

\section{Référence électronique}

Michael Richard Jackson Bonner, « James Howard-Johnston. The Sasanians' Strategic Dilemma », Abstracta Iranica [En ligne], Volume 32-33 | 2013, document 173, mis en ligne le 01 juillet 2016, consulté le 03 octobre 2020. URL : http://journals.openedition.org/abstractairanica/40518 ; DOI https://doi.org/10.4000/abstractairanica.40518

Ce document a été généré automatiquement le 3 octobre 2020.

Tous droits réservés 


\title{
James Howard-Johnston. The Sasanians' Strategic Dilemma
}

\author{
Michael Richard Jackson Bonner
}

\section{RÉFÉRENCE}

James Howard-Johnston. « The Sasanians' Strategic Dilemma », in : H. Börm, J. Wiesehöfer, eds., Commutatio et Contentio: Studies in the Late Roman, Sasanian, and Early Islamic Near East in Memory of Zeev Rubin. Düsseldorf, Wellem Verlag, 2010, p. 37-70.

1 Cet article traite, comme le suggère le titre, des dilemmes stratégiques auxquels les Sassanides étaient confrontés : la série de guerres contre les Romains, celle contre les Hephtalites, la montée du pouvoir des Turcs pendant le règne de Hosrow Anūšīrvān, et la succession de crises annonçant la chute de l'empire sassanide. Dans son style inimitable, l'A. décrit et analyse l'histoire de la grande offensive militaire lancée par Hosrow II contre l'empire romain et la sévère contre-attaque menée par l'empereur Héraclius. Cela est sûrement la partie la plus intéressante de l'article. Howard-Johnston décrit la géostratégie sassanide comme une tentative de gérer des engagements militaires sur deux zones frontalières. Selon l'A. la réponse particulière de Hosrow II à ce problème stratégique était de conquérir l'empire romain et de l'annexer à l'Iran une démarche qui a presque réussi. L'article se termine au moment où les nuages ténébreux de la guerre commencent de nouveau à s'abattre sur l'Iran, à la veille de la conquête arabe. 


\section{AUTEURS}

MICHAEL RICHARD JACKSON BONNER

Oxford 